\title{
Sentinel nyirokcsomó-biopszia melanoma malignumban: 10 év tapasztalatának eredményei a DEOEC Bôrgyógyászati Klinikáján
}

\section{Sentinel lymph node biopsy: results of 10 years' experience at the Department of Dermatology, Medical and Health Science Center, University of Debrecen}

\author{
POKOL EVELIN DR. ${ }^{1,2}$, DEIM NIKOLETTA DR. ${ }^{1,3}$, VERES IMRE DR. ${ }^{1}$, \\ GALUSKA LÁSZLÓ DR. ${ }^{4}$, ERDEI IRÉN DR. ${ }^{1.5}$, DEZSÔ BALÁZS DR.${ }^{6,7}$, PÉTER ZOLTÁN DR. ${ }^{1}$, \\ REMENYIK ÉVA DR. ', EMRI GABRIELLA DR. ${ }^{,}$, JUHÁSZ ISTVÁN DR. ${ }^{1,8}$
}

\begin{abstract}
Debreceni Egyetem, Klinikai Központ, Bőrgyógyászati Klinika, Debrecen', Magyarország, Kenézy Gyula Oktató Kórház és Rendelőintézet, Bőrgyógyászati Szakambulancia², Debrecen, Magyarország, St. Vinzenz Krankenhaus, Hanau³, Németország, Debreceni Egyetem, Klinikai Központ, Nukleáris Medicina Intézet ${ }^{4}$, Debrecen, Magyarország, Debreceni Egyetem, Klinikai Központ, Aneszteziológiai és Intenzív Terápiás Tanszék ${ }^{5}$, Debrecen, Magyarország, Debreceni Egyetem, Klinikai Központ, Pathológiai Intézet ${ }^{6}$, Debrecen, Magyarország, Debreceni Egyetem, Fogorvostudományi Kar, Mikrobiológiai és Pathológiai Tanszék ${ }^{7}$, Debrecen, Magyarország,

Debreceni Egyetem, Fogorvostudományi Kar, Fogorvosi Mútéttani Koordináló Tanszék ${ }^{8}$,
\end{abstract} Debrecen, Magyarország

\section{ÖSSZEFOGLALÁS}

Retrospektív vizsgálat során a Debreceni Egyetem, Orvos és Egészségtudományi Centrum, Börgyógyászati Klinikán 2000. január és 2009. december között elvégzett sentinel nyirokcsomó biopszián átesett betegek adatait dolgozták fel a szerzók. A vizsgálat célja, hogy a sentinel nyirokcsomó biopszia szerepét megitéljék a többi prognosztikai faktor vonatkozásában. 206 beteg közül 182 beteg adatai voltak alkalmasak a tudományos feldolgozás céljaira, melyek között 26 esetben találtak pozitív, azaz tumorsejteket tartalmazó órszem nyirokcsomót, és 156 esetben negatívnak bizonyult a biopszia. A sentinel pozitív betegeknél szignifikánsan magasabb arányban figyelhettünk meg nagyobb tumorvastagságot ( $p=0,00001)$ és inváziós mélységet $(p=0,0007)$. A két betegcsoportban a progresszió $(p=0,01)$, a betegségmentes $(p=0,002)$ és az össztúlélés ( $p=0,00007)$ vonatkozásában is szignifikáns különbség mutatkozott, amelyeket a KaplanMeyer túlélési görbék jól demonstrálnak. Jelentős, de statisztikailag nem szignifikáns különbség mutatkozott a két betegcsoport között az exulceráció tekintetében $(p=0,06)$. A sentinel nyirokcsomó pozitivitás magasabb arányban fordult elö kifekélyesedett tumor, szignifikánsan magasabb arányban fordult elö nagyobb tumor vastagság, nagyobb inváziós mélység esetén és ezeknek a betegeknek mind a tünetmentesmind az össztúlélése szignifikánsan alacsonyabb volt. Mivel

\section{SUMMARY}

Authors have analyzed in a retrospective study the clinical data of patients who had sentinel lymph node dissection (SLND) between 2000 January and 2009 December. The goal was to judge the value of the method in the context of other prognostic markers.

Of the 206 patients operated with SLND 182 patients were suitable for evaluation. The histopathological examination was negative in 156 cases, and revealed 26 positive lymphnodes, which were harboring a metastatic deposit.

Patients with positive sentinel node biopsy had significantly thicker tumors $(p=0,00001)$ and depth of invasion $(p=0,0007)$. There was also a significant difference noted in tumor progression $(p=0,01)$, in disease-free survival $(p=0,002)$ and overall survival ( $p=0,00007)$ rate of patients as indicated on comparative Kaplan-Meyer survival diagrams. There was martked, but statistically not significant difference $(p=0,06)$ between the two patient groups with regards to exulceration.

Since the differences between the two groups identified by SLND are statistically significant with regards to most analyzed parameters, a statement can be made about the outstanding prognostic value of

Levelezổ szerzô: Dr. Juhász István

e-mail: ijuhi@yahoo.com 
a két csoport között statisztikailag szignifikáns a különbség, ezért a vizsgálat alapján megállapítható, hogy a sentinel nyirokcsomó biopszia prognosztikai szempontból kiemelkedö jelentöségü. Kapott eredményeink azokat az irodalmi adatokat támasztják alá, melyek szerint az örszem nyirokcsomó vizsgálat a melanoma diagnosztika egyik fontos alappillére.

\section{Kulcsszavak: ôrszem nyirokcsomó-biopszia - melanoma malignum - prognosztikai faktorok}

sentinel node biopsy. In our sentinel node positive group there was an increased prevalence of exulceration, greater invasion depth and disease progression with reduced survival rates. These results are in accordance with most of the literature data, providing further support for the use of SLND in melanoma diagnostics.

\section{Key words: \\ sentinel lymph node biopsy - malignant melanoma - prognostic factors}

A sentinel nyirokcsomó diagnosztika alapja, hogy a daganat nyirokelvezetése előre meghatározható, melynek első állomása az őrszem nyirokcsomó. Ennek tumoros érintettsége érzékeny mutatója a regionális nyirokcsomó státusznak (1). Az ôrszem nyirokcsomó elmélete Gouldtól származtatható, aki 1960-ban közölte parotis daganatos betegeivel kapcsolatos megfigyeléseit (2).

Canabas 1977-ben közölte peniscarcinomás betegein végzett lymphangiográfiás vizsgálatainak eredményeit. Megállapította, hogy a regionális áttétképződés elsố helye a megfelelő nyirokrégió egy meghatározható nyirokcsomója, az ôrszem nyirokcsomó (3).

Morton kidolgozta a kék festékkel történő jelölés technikáját, valamint pontosította a fogalmat. Örszem nyirokcsomó biopszia technikával melanomás betegeken elért eredményeit 1992-ben ismertette (4).

Hazánkban elsőként Török László és munkatársai végeztek sentinel nyirokcsomó biopsziát melanomás betegeken patent-blue kék festék használatával. (5) A radioaktív izotóppal történố jelölés technikáját 1997-ben az Országos Onkológiai Intézetben vezették be Liszkay Gabriella és munkatársai (6). A Debreceni Egyetem, Orvos és Egészségtudományi Centrum (DEOEC) Bôrgyógyászati Klinikán 2000 januárjától végzünk ôrszem nyirokcsomó vizsgálatot a regionális nyirokcsomó tumoros érintettségének meghatározására.

\section{Anyag és módszer}

A DEOEC Bôrrgyógyászati Klinikáján 2000. január- 2009. december között 206 primer törzsi vagy végtagi lokalizációjú cutan melanoma malignummal bíró betegnél végeztünk sentinel nyirokcsomó eltávolítást, ebbốl 182 beteg követése valósult meg. Dolgozatunk e betegek retrospektív vizsgálatán alapul. A primer tumor becsült vastagságától, anatómiai helyétôl, a beteg elôzetes kivizsgálásától és általános állapotátó függốen, egy vagy két ülésben távolítottuk el az elsôdleges daganatot és az ôrszem nyirokcsomót. A legújabb ajánlások alapján is az 1-4 mm vastagságú melanomák képezik az ôrszem nyirokcsomó-biopszia fố indikációját (7). Egyes tanulmányokban a vastag (Breslow tumorvastagság $>4 \mathrm{~mm}$ ) melanomával bíró betegeket vizsgálva megállapították, hogy bizonyos kritériumok alapján szelektált betegcsoportban a sentinel biopszia elvégzése szignifikánsan magasabb össz- és betegségmentes túlélést eredményezett. (8) Klinikánkon a 182 betegból 27 esetben (fiatal életkor, elôzetes megítéléskor bizonytalan vastagság, idônyerés miatti egy üléses kombinált mútét) történt biopszia $4 \mathrm{~mm}$-nél vastagabb me lanománál.

Az elmúlt években egyre több cikk jelent meg a vékony (Breslow tumorvastagság $<1 \mathrm{~mm}$ ) melanomák esetén végzett nyirokcsomó biopszia létjogosultságáról. A 0,75-0,99mm vastagságú daganatoknál a tumorosan érintett nyirokcsomók aránya a $20 \%$-t is elérheti, ezér egyes szerzók $1 \mathrm{~mm}$ alatt ulceráció vagy IV-V Clark-féle invázió mélység esetén javasolják a biopsziát $(9,10)$. Klinikánkon 61 esetben (elốzetes megítéléskor bizonytalan vastagság, sérült vagy kifekélyesedett tumor) távolítottuk el az ôrszem nyirokcsomót $1 \mathrm{~mm}$ alatti tumorvastagság esetén.

A tumor köré kb. fél cm-re 2-4 helyre intracután fecskendezzük a $99 \mathrm{mTc}-\mathrm{mal}$ jelölt nanoalbumin radiokolloidot. Törzsi lokalizáció esetén lehetôség van dinamikus preoperativ lymphoscintigráfiás vizsgálatra, melynek segítségével megállapítható a nyirokelvezetés iránya. Az operáció közben alkalmazott kézi gamma szondával ellenôrizhetjük az izotóp dúsulását (1. ábra). A sentinel nyirokcsomó-dúsulás legalább

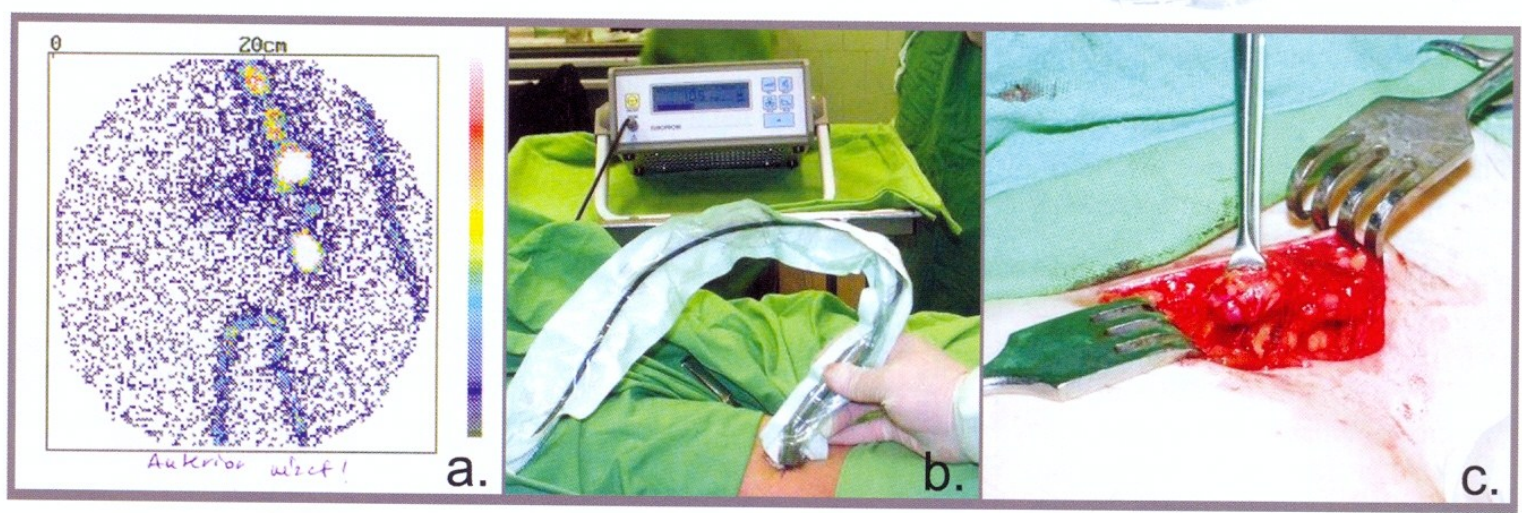

1. ábra

A gamma kamerával készített regisztrátum a) alapján intraoperatív gamma szondás detektálással b) lokalizáljuk a nyirokcsomó helyzetét, melyet sebészi módszerrel kipreparálunk c) és szövettani feldolgozásra küldünk 
tízszer nagyobb, mint a környezố többi nyirokcsomóé. Az izotóppal végzett identifikálás diagnosztikus biztonságán egy korábbi, nem publikált belsổ pilot tanulmány szerint nem változtatott a patentkék festék és izotóptechnika együttes alkalmazása. A kombinált módszer megbízhatósága egyes tanulmányok szerint 95-99\%-ra tehetô (6). Kék festéket gyakorlatunkban csak bizonyos anatómiai szituációkban (pl. nyirokrégió közelében levố elsôdleges tumor) alkalmaztunk.

A primer daganatok és az ôrszem nyirokcsomó(k) szövettani feldolgozása intézetünkben formalinos fixálást és paraffinos beágyazást követốen hagyományos hematoxilin-eozin festéssel illetve kiegészító S-100 protein, HMB-45 és esetenként Melan-A antitestekkel végzett immunhisztokémiai eljárással történik. Az őrszem nyirokcsomó tumoros érintettsége vagy klinikailag kimutatható regionális nyirokcsomó áttét esetén regionális blokkdisszekcióra került sor.

A betegek követése fizikális vizsgálattal és a szokásos képalkotó eljárásokkal történik: lágyrész $\mathrm{UH}$, hasi $\mathrm{UH}$, mellkas röntgen, szükség esetén csontscan, koponya-, mellkas-, hasi CT és MR, valamint PET-CT vizsgálatokat végzünk. A vizsgálat során a SN negativ betegek átlagos követési ideje 56,5 (15-119) hónap, a SN pozitiv betegeké 50,7 (15-110) hónap volt.

\section{Eredmények}

A DEOEC Bôrgyógyászati Klinikáján 2000. január- 2009. december között 206 primer cutan melanoma malignummal bíró betegnél végeztünk sentinel nyirokcsomó eltávolítást. Ebből 7 esetben (2\%) nem találtunk nyirokcsomót, míg 98\%-ban sikerült egy vagy több sentinel nyirokcsomót azonosítanunk. Ez az irodalomban található 95\%os megbízhatósági tartományon belül van (6). 29 esetben (14\%) tumorosan érintett és 170 esetben $(86 \%)$ tumormentes ôrszem nyirokcsomót találtunk.

11 elhalálozott beteg (6 nô, 5 férfi) nem melanomában halt meg, így az ô esetük nem került feldolgozásra. Ez a csoport 3 sentinel pozitív, 7 sentinel negatív betegból állt, 1 beteg pedig abba a csoportba tartozott, amelyiknél ôrszem nyirokcsomó nem volt kimutatható (ld. elóbb). 7 beteget ismeretlen tartózkodási helyük miatt nem lehetett tovább követni, mind a 7 esetben tumormentesek voltak a nyirokcsomók.

A vizsgálat számára elérhetổ 182 kezelt beteg közül 106 nő $(58,2 \%)$ és 76 férfi $(41,8 \%)$ volt, a betegeink átlagéletkora 54,71 év (22 -79) volt.

A sentinel biopszia prognosztikai jelentőségét a fentieknek megfelelôen 182 beteg további követésével lehetett tanulmányozni, melyek közül 26 esetben találtunk pozitív és 156 esetben negatív őrszem nyirokcsomókat.
A primer tumorok elhelyezkedését is megvizsgáltuk és regisztráltuk. Az alsó végtag területén és a törzsön csaknem azonos arányban fordultak elő a melanomák, míg legkisebb számban a felső végtagi lokalizációban észleltünk tumorokat (1. táblázat). A primer tumorok szövettani

\begin{tabular}{|c|c|c|c|c|}
\hline & $\begin{array}{c}\text { Felső végtag } \\
\mathrm{N}=44\end{array}$ & $\begin{array}{c}\text { Alsó végtag } \\
\mathrm{N}=68\end{array}$ & $\begin{array}{c}\text { Törzs } \\
\mathrm{N}=69\end{array}$ & $\begin{array}{c}\text { Egyéb } \\
\mathrm{N}=1\end{array}$ \\
\hline $\begin{array}{c}\text { Sentinel pozitív } \\
\mathrm{N}=26\end{array}$ & $4(15,4 \%)$ & $10(38,5 \%)$ & $12(46,1 \%)$ & $0(0,0 \%)$ \\
\hline $\begin{array}{c}\text { Sentinel negatív } \\
\mathrm{N}=156\end{array}$ & $40(25,6 \%)$ & $58(37,2 \%)$ & $57(36,5 \%)$ & $1(0,7 \%)$ \\
\hline
\end{tabular}

1. táblázat

A primer tumorok lokalizáció szerinti megoszlása

\begin{tabular}{|c|c|c|c|c|}
\hline & $\begin{array}{c}\text { SSM } \\
\mathrm{N}=127\end{array}$ & $\begin{array}{c}\text { NM } \\
\mathrm{N}=41\end{array}$ & $\begin{array}{c}\text { ALM } \\
\mathrm{N}=13\end{array}$ & $\begin{array}{c}\text { LMM } \\
\mathrm{N}=1\end{array}$ \\
\hline $\begin{array}{c}\text { Pozitív sentinel } \\
\text { biopszia N=26 }\end{array}$ & $11(42,3 \%)$ & $11(42,3 \%)$ & $4(15,4 \%)$ & $0(0,0 \%)$ \\
\hline $\begin{array}{l}\text { Negatív sentinel } \\
\text { biopszia N=156 }\end{array}$ & $116(74,3 \%)$ & $30(19,2 \%)$ & $9(5,8 \%)$ & $1(0,7 \%)$ \\
\hline \multicolumn{3}{|c|}{$\begin{array}{l}\text { Superficial spreading melanoma : SSM, Nodularis melanoma: NM, Akrolentiginosus } \\
\text { melanoma: ALM, Lentigo maligna melanoma: LMM }\end{array}$} \\
\hline
\end{tabular}
2. táblázat

A primer tumorok szövettani típusainak megoszlása a sentinel pozitív és negatív betegek között

\begin{tabular}{|c|c|c|}
\hline & $\begin{array}{c}\text { Exulcerált } \\
\mathrm{N}(\%)\end{array}$ & $\begin{array}{c}\text { Nem exulcerált } \\
\mathrm{N}(\%)\end{array}$ \\
\hline $\begin{array}{c}\text { Pozitív sentinel } \\
\text { biopszia } \mathrm{N}=26\end{array}$ & $9(34,6 \%)$ & $17(65,4 \%)$ \\
\hline $\begin{array}{c}\text { Negatív sentinel } \\
\text { biopszia } \mathrm{N}=156\end{array}$ & $27(18,2 \%)$ & $129(81,8 \%)$ \\
\hline
\end{tabular}

3. táblázat

A primer tumor kifekélyesedésének megoszlása a két betegcsoport között $(\mathrm{p}=0.060)$

\begin{tabular}{|lc|c|c|}
\hline \multicolumn{2}{|c|}{$\begin{array}{c}\text { Breslow szerinti } \\
\text { tumorvastagság }\end{array}$} & $\begin{array}{c}\text { Pozitív sentinel biopszia } \\
\mathrm{N}=26\end{array}$ & $\begin{array}{c}\text { Negatív sentinel biopszia } \\
\mathrm{N}=156\end{array}$ \\
\hline$<1,00 \mathrm{~mm}$ & $\mathrm{~N}(\%)$ & $3(11,5 \%)$ & $58(37,1 \%)$ \\
\hline $1,01-2,00 \mathrm{~mm}$ & $\mathrm{~N}(\%)$ & $4(15,4 \%)$ & $55(34,6 \%)$ \\
\hline $2,01-4,00 \mathrm{~mm}$ & $\mathrm{~N}(\%)$ & $8(31 \%)$ & $27(18,2 \%)$ \\
\hline$>4,00 \mathrm{~mm}$ & $\mathrm{~N}(\%)$ & $11(42,3 \%)$ & $16(10,1 \%)$ \\
\hline
\end{tabular}

\section{4. táblázat}

A primer tumor Breslow szerinti tumorvastagságának megoszlása a pozitív és negatív ốrszemnyirokcsomóval bíró betegekben $(\mathrm{p}=0.04)$

\begin{tabular}{|ll|c|c|}
\hline & & $\begin{array}{c}\text { Pozitív sentinel biopszia } \\
\mathrm{N}=26\end{array}$ & $\begin{array}{c}\text { Negatív sentinel biopszia } \\
\mathrm{N}=156\end{array}$ \\
\hline Clark I. szint & $\mathrm{N}(\%)$ & $0(0,0 \%)$ & $2(1,3 \%)$ \\
\hline Clark II. szint $\mathrm{N}(\%)$ & $1(3,8 \%)$ & $15(10,1 \%)$ \\
\hline Clark III. szint & $\mathrm{N}(\%)$ & $9(34,8 \%)$ & $98(61,6 \%)$ \\
\hline Clark IV. szint & $\mathrm{N}(\%)$ & $14(53,8 \%)$ & $37(24,5 \%)$ \\
\hline Clark V. szint & $\mathrm{N}(\%)$ & $2(7,6 \%)$ & $4(2,5 \%)$ \\
\hline
\end{tabular}

5. táblázat

Primer tumor Clark szerinti inváziós mélységének megoszlása a két betegcsoportban (Fisher egzakt próba p=0.01) 
a)

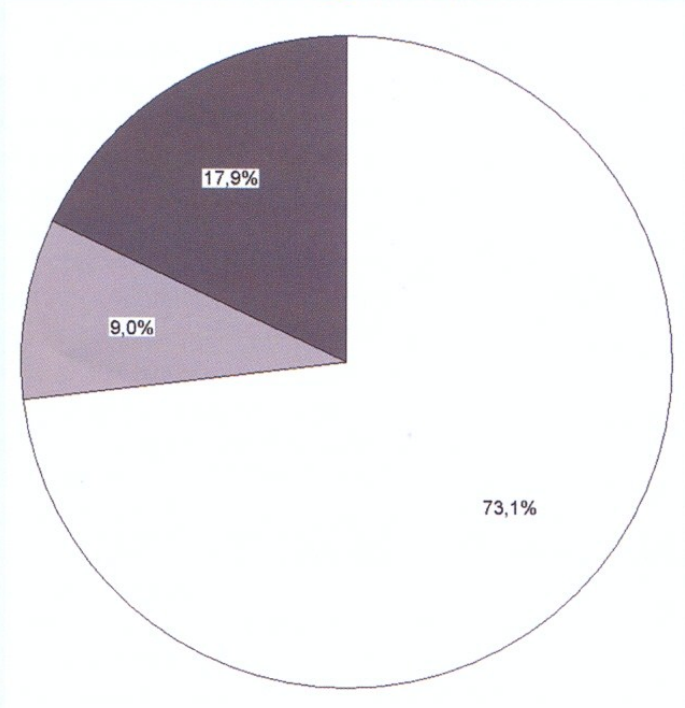

b)

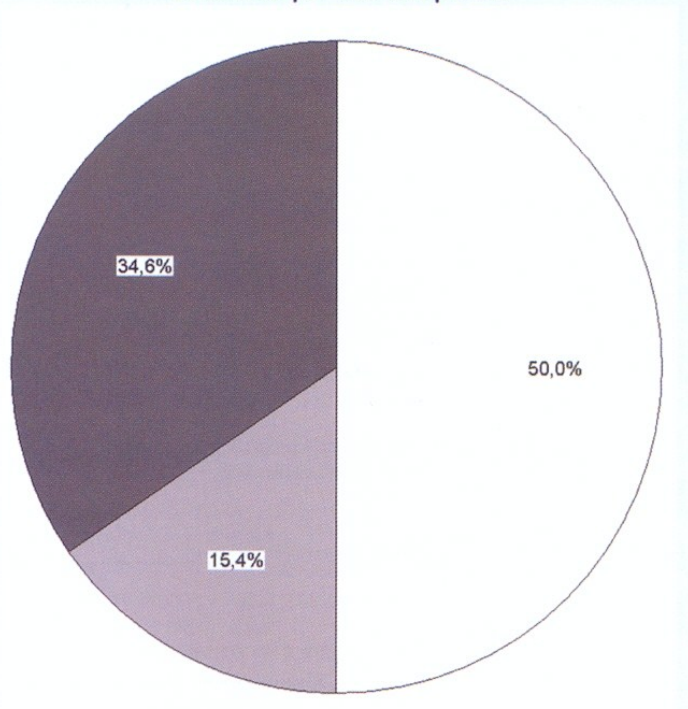

progresszió nélkül

hematogén progresszió

lymphogén progresszió

\section{2. ábra}

Az alapbetegség progressziója a két betegcsoportban (Fisher egzakt próba p=0.046). A metasztázis mentesség, illetve a hematogén valamint lymphogén áttétképződés alakulása a) a tumormentes és b) a tumorosan érintett sentinel nyirokcsomóval bíró betegekben

csoportosítását vizsgálva a felszínesen terjedô forma elốfordulása volt a leggyakoribb, ezt követte a noduláris melanoma, kevésbé gyakori volt az akrolentiginozus melanoma, és csak egy esetünk volt lentigo maligna melanoma (2. táblázat). Egy másik igen fontos prognosztikai faktor tekintetében megállapíthattuk, hogy a sentinel pozitív betegekben magasabb arányban fordult elô a tumor kifekélyesedése, azonban Fisher-féle egzakt próbával vizsgálva ez nem bizonyult szignifikánsnak $(\mathrm{p}=0,06)(3$. táblázat). A Breslow-féle tumor vastagságban szignifikáns különbség mutatkozott a betegcsoportok között a Wilcoxon próba alapján, a sentinel pozitív betegek esetében szignifikánsan magasabb arányban fordult elő nagyobb tumorvastagság, mint a tumorosan nem érintett nyirokcsomójú betegekben (11) (4. táblázat). A Clark-féle besorolás szerint a pozitív sentinel biopsziájú betegek között nagyobb arányban fordultak elő az elôrehaladottabb, IV és V inváziós mélységú melanomák $(53,8 \%$ illetve $7,6 \%)$, mint a negatívak esetében (24,5\% illetve $2,5 \%)$. A Wilcoxon próba alapján itt is a korábbi irodalmi adatoknak megfelelő (12) szignifikáns különbség mutatkozott (5. táblázat).

A 26 sentinel pozitív betegnél blokkdisszekció történt, melynél 9 esetben $(34,6 \%)$ találtunk további tumorosan érintett nyirokcsomókat, és ebből a követés során 5 betegnél következett be progresszió: 2 esetben haematogén, 3 esetben lymphogén úton. Azoknál a sentinel pozitív bete- geknél, akiknél az elvégzett blokkdisszekció negatív eredménnyel járt, a későbbi utókövetés során 47\%-ban alakult ki áttétképződés, 5 esetben hematogén, 3 esetben lymphogén úton. A fenti adatokat összegezve a sentinel pozitív betegek 50\%-ában volt észlelhetô progresszió a későbbiekben, akik közül eddig 11 beteget vesztettünk el a betegség elốrehaladása miatt.

A 156 sentinel negatív betegből 42 esetben $(26,9 \%)$ lépett fel az alapbetegség progressziója: 14 haematogén (33\%) és 28 lymphogén (67\%) disszemináció történt. Ebben a betegcsoportban az ốrszem nyirokcsomó régiójában 10 nyirokcsomó-recidívát észleltünk, azaz a vizsgálat szenzitivitása (valódi pozitív esetek/(valódi pozitív esetek + álnegatív esetek) 73\% volt, amely érték megfelel a nemzetközi irodalomnak (12). A negatív nyirokcsomó státuszú betegek közül eddig 23-t vesztettünk el. A betegkövetés alapján megállapítható, hogy a sentinel pozitív csoportban Wilcoxon próbával igazoltan szignifikánsan magasabb arányban történt progresszió $(\mathrm{p}=0,01)(2$ a ábra $)$. Ezt a megfigyelést támasztják alá a túlélési (Kaplan-Meyer) grafikonok is, mind a betegségmentes ( $3 a$. ábra), mind pedig a teljes túlélés ( $3 b$. ábra) vonatkozásában. A sentinel nyirokcsomó státuszhoz hasonló túlélésbeli különbség mutatkozik akkor is, ha a primer tumorok kifekélyesedését hasonlítjuk össze ( $3 c$. és $3 d$. ábra) vagy ha a tumor tipusokat és a primer tumorok vastagságát vizsgáljuk (nincs ábrázolva). 

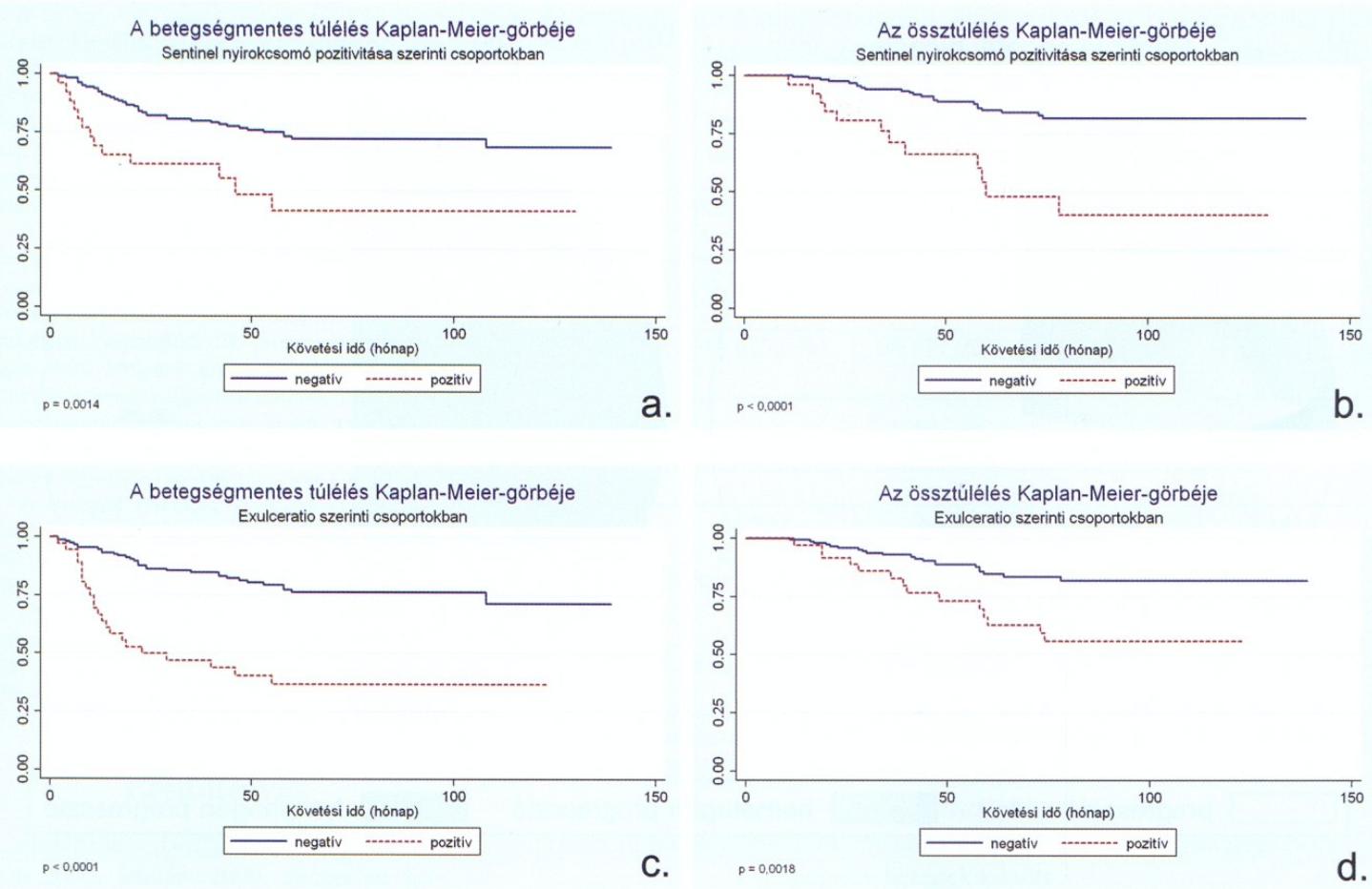

3. ábra

A melanomás betegek túlélésének Kaplan-Meyer szerinti grafikus ábrázolása. Jól látható különbség mutatkozik mind a) a betegségmentes, mind pedig b) a teljes túlélés vonatkozásában a betegek sentinel nyirokcsomó státusza szerint. Ha a primer tumorok kifekélyesedését hasonlítjuk össze, hasonló különbséget találunk a betegek c) betegségmentes és

d) teljes túlélése között

Az áttétképződéseket vizsgálva nem volt különbség a tumoros szóródás útvonalát illetően, a haematogén illetve lymphogén áttétek mindkét populációban 1:2 arányban jöttek létre. A sentinel pozitív csoportban $31 \%$ vs $69 \%$ (4 / 9 eset), a negatív csoportban $33 \%$ vs $67 \%$ (14 / 28 eset), ami a tankönyvi adatokkal egyezô (14).

\section{Megbeszélés}

A melanoma malignum terápiájában sokáig meghatározó volt az az álláspont, amely szerint az eltávolított tumorhoz tartozó nyirokcsomó régió elektív disszekciója preventív hatású, a daganat továbbterjedését mérsékelni képes. Az alsó végtagi melanomás betegek körében végzett, WHO által koordinált randomizált klinikai vizsgálat mutatta ki, hogy a jelentős járulékos morbiditás mellett az elektív blokkdisszekciós mútét elvégzése nem változtatta meg a betegek túlélését a másik betegcsoporthoz képest, akiknél csak a negyedévenként esedékes nyomon követés során klinikailag észlelt nyirokcsomó metasztázis esetén végezték el a mútétet (15). Így a melanoma elfogadott kezelési stratégiájává az obszerváció (wait and see) módszere válhatott. A melanomával operált betegek körében a nyirokcsomó metasztázissal rendelkezők csoportjának klinikai tünetek előtti beazonosítása céljából fejlesztették ki a sentinel nyirokcsomó detektálására alkalmas kolloid festék beadásán alapuló módszert (4). A technikát hamarosan kiegészítő radiokolloid jelölés segítségével továbbfejlesztették (16) és az napjainkra a stádium besorolás egyik fontos tényezőjévé vált. 2006-ban publikált nyomon követéses vizsgálatai jelentôs mortalitás különbséget igazoltak öt évnél a SLND negatív $(90,2 \pm 1,3 \%)$ és a SLND pozitív $(72,3 \pm 4,6 \%)$ betegcsoportok vonatkozásában. Ez az észlelés alátámasztja a módszer független prediktív tényezô szerepét (17). Elterjedóben van olyan vélekedés is, amely szerint a nyirokcsomóban megjelenő áttét lassú növekedési dinamizmusára (inkubációs szakasz) alapozva az eljárás kuratív is lehet, tehát a nyirokcsomó régió további mútéti kezelése, a komplettáló blokk-disszekció (CLND) elvégzése már nem is szükséges, a túlélési paramétereket nem javítja tovább (18). A SLND módszerét kidolgozó munkacsoport legújabb, 2000 beteg nyomon követésén alapuló, lezáró tanulmánya ismételten megerósítette a csak obszervációban részesülő melanomás betegek és a SLND-n valamint komplettáló nyirokcsomó-blokkdisszekción átesett betegek csoportjai között, a betegségmentes túlélés és a melanoma specifikus túlélés vonatkozásában észlelt szignifikáns különbség alapján a módszer előnyös voltát. A tanulmány megállapításai szerint a közepes vastagságú melanomák csoportjában a 10 éves betegségmentes túlélés a 
sentinel pozitív eseteknél 62,1\%-nak, míg a sentinel negatív betegek esetében $85,1 \%$-nak bizonyult, amely igazolja a SLND prognosztikai értékét (19).

A DEOEC Bőrgyógyászati Klinikán 2000 januárja óta végzünk őrszem nyirokcsomó biopsziát a regionális nyirokcsomók tumoros érintettségének meghatározására. Tanulmányunkban a 2000. január és 2009. december között sentinel biopszián átesett betegink adatait dolgoztuk fel. A módszert $98 \%$-os sikerrel alkalmaztuk. A 182 beteg (76 férfi, 106 nô) követése során a hisztológiailag pozitív illetve negatív ốrszem nyirokcsomójú (26 vs 156) betegcsoportokat hasonlítottuk össze. A két csoport összevetése során az exulceráció tekintetében különbség, míg a Breslow-féle tumorvastagság és a Clark-féle inváziós mélység tekintetében szignifikáns különbség mutatkozott. Vizsgáltuk továbbá a nemek arányát, az átlagéletkort, a primer daganatok lokalizációját, a szövettani csoportok arányát illetve az elsố áttét megjelenésének a helyét, a betegek túlélését és ezen paraméterek tekintetében az irodalmi közlésekkel egyezố adatokat kaptunk. A két csoport utánkövetési adatai alapján bizonyítást nyert, hogy a sentinel nyirokcsomó biopszia a tumor progresszió jól használható prognosztikai faktora. Elmondható, hogy a sentinel nyirokcsomó biopszia nélkülözhetetlen diagnosztikus eljárás is, hiszen mára mind a TNM klasszifikáció, mind a pontos stádium meghatározás alapvetô elemévé vált. Eredménye alapján korán elvégezhetố a regionális, radikális lymphadenectomia, valamint a fokozott rizikójú, adjuváns kezelésre szoruló betegek szelektálása.

\section{Köszönetnyilvánítás}

Köszönjük Dr. Kardos László matematikus- biostatisztikusnak a statisztikai számítások elvégzését. Hálásan köszönjük a DEOEC Bốrgyógyászati Klinika mûtősnőinek, Nagyné Dobi Dórának és Tomasovszkyné Vécsey Ibolyának a lelkiismeretes segítséget az adatok összegyújtésében. A cikk a TÁMOP-4.2.2.A-11/1/KONV2012-0023 azonosítószámú, „VÉD-ELEM”, valamint a TÁMOP4.2.2.A-11/1/KONV-2012-0031 sz. és az OTKA NK $101680 \mathrm{sz}$ kutatási pályázatok támogatásával jött létre. Kettôs elsố szerzőség: P.E. és D.N. a DE OEC Bôrklinika TDK szakkörös orvostanhallgatóiként egyenlôen vettek részt az adatgyújtésben és a dolgozat elkészítésében.

\section{IRODALOM}

1. Péley G., Köves I., Sinkovics I., Farkas E., Dubecz S., Kovács T. Keresztes S., Vámosi-Nagy I.: Az ốrszemnyirokcsomó-biopszia jelentôsége a daganatsebészetben, LAM, (2002) 12(1), 18-26.

2. Gould E. A., Winship T., Philbin P. H., Kerr H. H.: Observation on a "sentinel node" in cancer of the parotid, Cancer (1960) 13, 77-78.

3. Cabanas R. M.: An approach for the treatment of penile carcinoma, Cancer (1977) 39, 456-466.

4. Morton D. L., Wen D. R., Wong J. H., Economou I S. Cagle L. A., Storm F. K., Foshag L. J., Cochran A. J.: Technical details of intraoperative lymphatic mapping for early stage melanoma. Arch. Surg. (1992)127, 392-399.

5. Török L., Mari B., Fórizs A., Tápai M., Ócsai H.: A sentinel nyirokcsomó vizsgálatának jelentôsége melanoma malignumban. Orv Hetil (1998) 139, 1339-1341.
6. Liszkay G., Farkas E., Péley G., Sinkovics I., Péter I., Bánfalvi T., Fejốs Zs., Gilde K.: Preoperatív limfoszcintigráfiával végrehajtott sentinel nyirokcsomó mútétek melanoma malignumban. Magyar Onkológia (2000) 44, 141-143.

7. Wong S. L., Balch C. M., Hurley P., Agarwala S. S., Akhurst T. J., Cochran A., Cormier J. N., Gorman M. Kim T. Y. McMasters K. M., Noyes R. D., Schuchter L. M. Valsecchi M. E., Weaver D. L., Lyman G. H.: Sentinel Lymph Node Biopsy for Melanoma: American Society of Clinical Oncology and Society of Surgical Oncology Joint Clinical Practice Guideline. J Clin Oncol. (2012) 30(23), 2912-2918

8. Gershenwald J. E., Mansfield P. F., Lee J. E., Ross M. I.: Role for lymphatic mapping and sentinel lymph node biopsy in patients with thick $(? 4 \mathrm{~mm})$ primary melanoma. Ann Surg Oncol. (2000) 7, 160-165.

9. Andtbacka R. H., Gershenwald J. E.: Role of sentinel lymph node biopsy in patients with thin melanoma. J Natl Compr Canc Netw. (2009) 7, 308-317.

10. Tomas-Mallebrera L., Rojo-Espana R., Marquima-Vila A., Gimeno-Clemente N., Morales-Suárez-Varela M. M.: Sentinel Lymph Node Biopsy in Patients With Melanoma, Actas Derm., (2010) 101(5), 428-436.

11. Lens M. B., Dawes M., Newton-Bishop J. A., Goodacre T.: Tumour thickness as a predictor of occult lymph node metastases in patients with stage I and II melanoma undergoing sentinel lymph node biopsy. Br J Surg. (2002) 89(10), 1223-1227.

12. Marghoob A. A., Koenig K., Bittencourt F. V., Kopf A. W., Bart $R$. S.: Breslow thickness and clark level in melanoma: support for including level in pathology reports and in American Joint Committee on Cancer Staging. Cancer. (2000) 88(3), 589-595.

13. Valsecchi M. E., Silbermins D., de Rosa N., Wong S. L., Lyman G. H.: Lymphatic mapping and sentinel lymph node biopsy in patients with melanoma: a meta-analysis. J. Clin. Oncol. (2011) 29(11), 1479-1487.

14. Meier F., Will S., Ellwanger U., Schlagenhauff B., Schittek B., Rassner G., Garbe C.: Metastatic pathways and time courses in the orderly progression of cutaneous melanoma. Br J Dermatol. (2002) 147(1), 62-70

15. Veronesi U., Adamus J., Bandiera D. C., Brennhovd O., Caceres E., Cascinelli $N$. et al.: Delayed regional lymph node dissection in stage I melanoma of the skin of the lower extremities. Cancer (1982) 49, 2420-2430.

16. Morton D. L., Thompson J. F., Essner R., Elashoff R., Stern S. L., Nieweg O. E., Roses D. F., Karakousis C. P., Mozzillo N., Reintgen D., Wang H. J., Glass E. C., Cochran A. J.: Validation of the accuracy of intraoperative lymphatic mapping and sentinel lymphadenectomy for early-stage melanoma: a multicenter trial. Multicenter Selective Lymphadenectomy Trial Group. Ann Surg. (1999) Oct;230(4), 453-463.

17. Morton D. L.1, Thompson J. F., Cochran A. J., Mozzillo N. Elashoff R., Essner R., Nieweg O. E., Roses D. F., Hoekstra H. J. Karakousis C. P., Reintgen D. S., Coventry B. J., Glass E. C., Wang H. J., MSLT Group.: Sentinel-node biopsy or nodal observation in melanoma. N Engl J Med. (2006) 355(13), 1307-1317.

18. A. P. T. van der Ploeg, A. C. J. van Akkooi, P. Rutkowski, M. Cook, O. E. Nieweg, C. R. Rossi, A. Testori, S. Suciu, C. Verhoef, A. M. M.: Eggermont for EORTC Melanoma Group. Prognosis in patients with sentinel node-positive melanoma without immediate completion lymph node dissection Brit J Surgery (2012) 99, 1396-1405.

19. Morton D. L., Thompson J. F., Cochran A. J., Mozzillo N., Nieweg O. E., Roses D. F., Hoekstra H. J., Karakousis C. P. Puleo C. A., Coventry B. J., Kashani-Sabet M., Smithers B. M. Paul E., Kraybill W. G., McKinnon J. G., Wang H. J., Elashoff R., Faries M. B., MSLT Group.: Final trial report of sentinelnode biopsy versus nodal observation in melanoma. $\mathrm{N}$ Engl $\mathrm{J}$ Med. (2014) 370(7), 599-609.

Érkezett: 2014. 05. 15

Közlésre elfogadva: 2014. 05. 29 